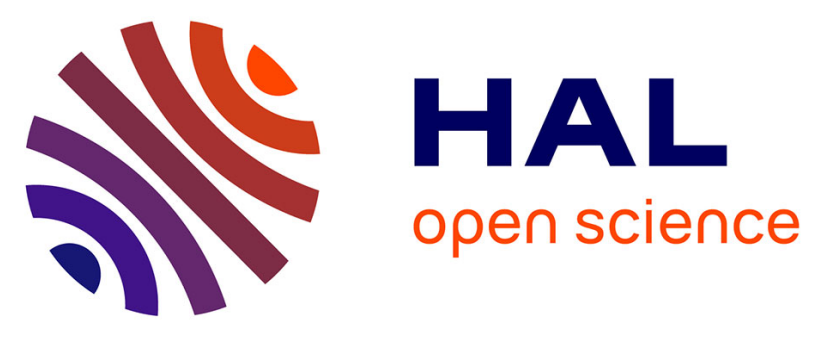

\title{
Multi-criteria decision making approaches for Facility Layout (FL) evaluation and selection: A survey
}

Mariem Besbes, Roberta Costa Affonso, Zolghadri Marc, Faouzi Masmoudi, Mohamed Haddar

\section{- To cite this version:}

Mariem Besbes, Roberta Costa Affonso, Zolghadri Marc, Faouzi Masmoudi, Mohamed Haddar. Multicriteria decision making approaches for Facility Layout (FL) evaluation and selection: A survey. Mohamed Haddar, Fakher Chaari, Abdelmajid Benamara, Mnaouar Chouchane, Chafik Karra, Nizar Aifaoui. Design and Modeling of Mechanical Systems-III, Springer, pp.613-622, 2017, 978-3-319-666969. 10.1007/978-3-319-66697-6_59. hal-01711799

\section{HAL Id: hal-01711799 \\ https://hal.science/hal-01711799}

Submitted on 22 Jan 2019

HAL is a multi-disciplinary open access archive for the deposit and dissemination of scientific research documents, whether they are published or not. The documents may come from teaching and research institutions in France or abroad, or from public or private research centers.
L'archive ouverte pluridisciplinaire $\mathbf{H A L}$, est destinée au dépôt et à la diffusion de documents scientifiques de niveau recherche, publiés ou non, émanant des établissements d'enseignement et de recherche français ou étrangers, des laboratoires publics ou privés. 


\title{
Multi-criteria decision making approaches for Facility Layout (FL) evaluation and selection: A survey
}

\author{
Mariem BESBES $^{1,2}$, Roberta COSTA AFFONSO ${ }^{1}$, Marc ZOLGHADRI ${ }^{1}$, \\ Faouzi MASMOUDI' ${ }^{2}$, Mohamed HADDAR ${ }^{2}$ \\ ${ }^{1}$ Quartz-Supmeca, 93407 Saint-Ouen, France \\ mariem.besbes@supmeca.fr, roberta.costa@supmeca.fr, marc.zolghadri@supmeca.fr \\ ${ }^{2}$ University of Sfax, LA2MP-ENIS, B.P 1173, 3038 Sfax, Tunisia \\ faouzi.masmoudi@enis.run.tn,mohamed.haddar@enis.rnu.tn
}

\begin{abstract}
The aim of this paper is to provide a survey related to the criteria that affect the effectiveness of a facility layout. The design criteria can be classified according to the previous research into two categories which are qualitative and quantitative indicators. Then, this paper presents a review of different MultiCriteria Decision Making (MCDM) techniques that have been proposed in the literature to pick the most suitable layout design. These methods are particularly suitable to deal with complex situations, including various criteria and conflicting goals which need to be optimized simultaneously. The review serves as a guide to those interested in how to evaluate and select the most appropriate layout which can handle an expanded range of manufacturing companies. Finally, we present a discussion followed by a conclusion.
\end{abstract}

Keywords: Multi-criteria decision making, facility layout evaluation, facility layout design selection, Survey.

\section{Introduction}

The layout problem is concerned with finding the most efficient arrangement of the facilities with the available floor area, evaluating the layout design alternatives and selecting the most appropriate design as illustrated in fig.1. The layout design problem can have a significant impact on the overall effectiveness of the manufacturing systems. Hence, it has been an active research area for several decades. A lot of research has been dedicated to present the different approaches for the generation of layout. Detailed review is provided by (Kusiak and Heragu 1987), 
(Meller and Gau 1996), (Singh and Sharma 2006), (Drira et al 2007), and (Nordin and Lee 2016). However, no research has been found to survey the multi-criteria layout evaluation and selection approaches through a literature review since except (Lin and Sharp 1999). The aim of this proposed study is to present a survey about the criteria and the techniques considered by the decision makers for evaluating and selecting the most appropriate layout. Hence, we will study the part B as shown in Fig. 1. This paper is organized as follows: Section 2 describes the evaluating criteria. Section 3 provides an overview of the multi-criteria decision approaches. An analysis of the current and future trends is discussed in section 4 followed by a conclusion.

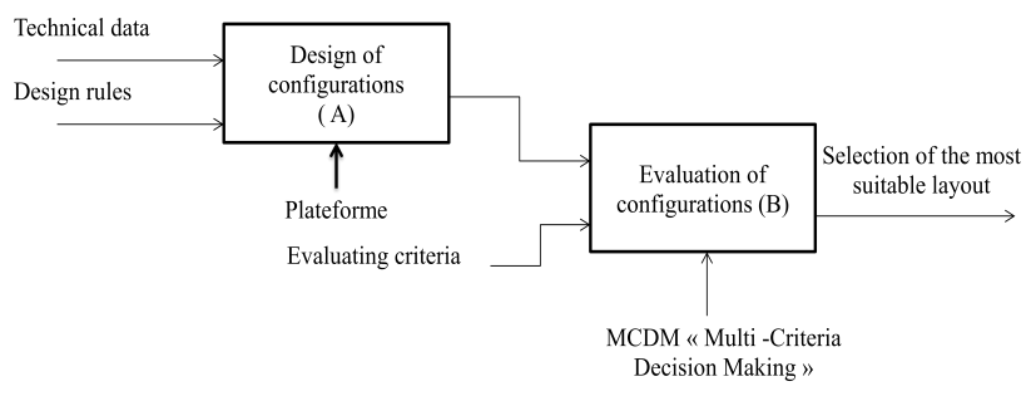

Fig. 1 Conceptual framework of facility layout problem

\section{Overview of the evaluating criteria}

In this section, we summarize the principal criteria found in the collected papers for the evaluation and selection of a new configuration among a set of available alternatives. These criteria can be classified into two categories: quantitative and qualitative.

\subsection{Quantitative criteria}

Distance is the most popular criterion considered by the designer for the evaluation of configurations. It was determined by the sum of the products of flow volume and rectilinear distance between the centroids of two facilities as shown in equation 1 . There is two ways for measuring the distances: distance between Input/ Output (I/O) points or centroid to centroid. The main objective function for facility layout problem is to minimise the material handling cost according to the travelled distance because handling work adds to cost but does not increase value to products; consequently any unnecessary movements should be avoided. 
$\operatorname{Cost}=\sum_{i} \sum_{j} f_{i j} * d_{i j}$

Note that: $f_{i j}$ is the material flow between the facilities $i$ and $\mathbf{j}$.

$d_{i j}$ is the distance between facilities.

Adjacency of facilities is highly suggested due to some factors such as noise, vibration, luminosity, sharing of operators or tools and Flow exchange density or frequency. It was determined by the sum of all positive relationships between adjacent facilities as shown in equation (2).

$$
\text { Adjacency }=\sum_{i} \sum_{j} r_{i j}{ }^{*} l_{i j}
$$

Note that $r_{i j}$ is the closeness rating and $l_{i j}$ is the contact perimeter length between facilities $i$ and $j$.

Shape ratio is defined as the maximum of the depth-to width and width-todepth ratio of the smallest rectangle that completely encloses the facilitate (Aiello et al. 2006; Aiello et al.2012)

Space consists of five types (Lin and Sharp 1999): space for production machinery and material handling equipment, space for storage, space for personal needs aisle space for material and personal movement and free space. Hence, the production area include value added area and non value added area (Raman et al.2009). It can be overused when there is not enough space for future activity or underused when the shop floor are not fully used. To examine the effectiveness of layout design, we should calculate the space utilisation rate as follows (Suo 2012):

$$
\boldsymbol{R}_{s}=\frac{\sum_{i} A_{i}}{\sum_{i} A_{i}+\sum_{j} B_{j}}
$$

Note that $A_{i}$ is the area of department $\mathrm{i}$ where equipment $\mathrm{i}$ is sitting and $B_{j}$ is the unusable space.

Products indicators are associated to throughput time, product earliness, product lateness, and product blocked time. (Ben cheikh 2015) and (Ben cheikh 2016) defined the throughput time as the period required for a single product to be produced. The product earliness is calculated when the product is finished before its due date. However, the product lateness is computed when the product is finished after its due date. These indicators are evaluated using event simulation software like Arena, Witness, ProModel. Product blocked time is the waiting time for the product in the queue until loaded on the machine to be processed.

Resources indicators are related to machine utilization, the number of machine, and the number of operators that are used in a configuration.

Work in process is the set of unfinished items waiting for further processing in a queue or buffer storage. Optimal configuration aims to minimize work in process. In fact, it requires storage space and cost. It affects the production rates by slowing at bottlenecks. 


\subsection{Qualitative criteria}

Flexibility is defined as the ability of the company to adapt to changes in its environment. In fact, flexibility is the ability to achieve a variety of tasks under a wide range of operating conditions. We find several type of flexibility:

Volume flexibility is defined as the ability to function profitably at different production volumes. This can be done by changing the number of facilities for example.

Routing flexibility is described as the ability of a product to change path during the production process.

Expansion flexibility is defined as the ease of increasing the production capacity of a production system. It can be quantified by the number of free space locations with good shape factors or usable area (Raman et al. 2009).

Accessibility has been defined by (Yang and Hung 2007) as the material handling and operators paths. While designing the layout, we should save enough space within or along the contours of the departments to allow the movement of materials and personnel. Moreover, all servicing and maintenance points should be readily accessible. For example, equipment should not be placed against a wall in such a manner that necessary maintenance cannot easily be carried out.

Human issues cluster involves several aspects. First, it is related to the ease of supervision control and communication between workers by the elimination for example of hidden corners. Second, other criteria that are related to environment, safety, security of operators should be taken into account.

Layout reconfigurability presents a facilitating level of rearrangement and/or alteration of facilities to respond to new situations (Abdi 2009). The five main criteria of layout reconfigurability are convertibility, modularity, mobility, reconfiguration speed, and scalability.

All of the criteria are not explained in the text. However, a survey of different criteria that are used in the literature to evaluate different layouts is provided in Table1 wherein twenty three criteria are tabulated in columns A to w in order to give a background for the designers. 
Table 1. A summary of evaluating criteria and techniques for facility layout evaluation and selection.

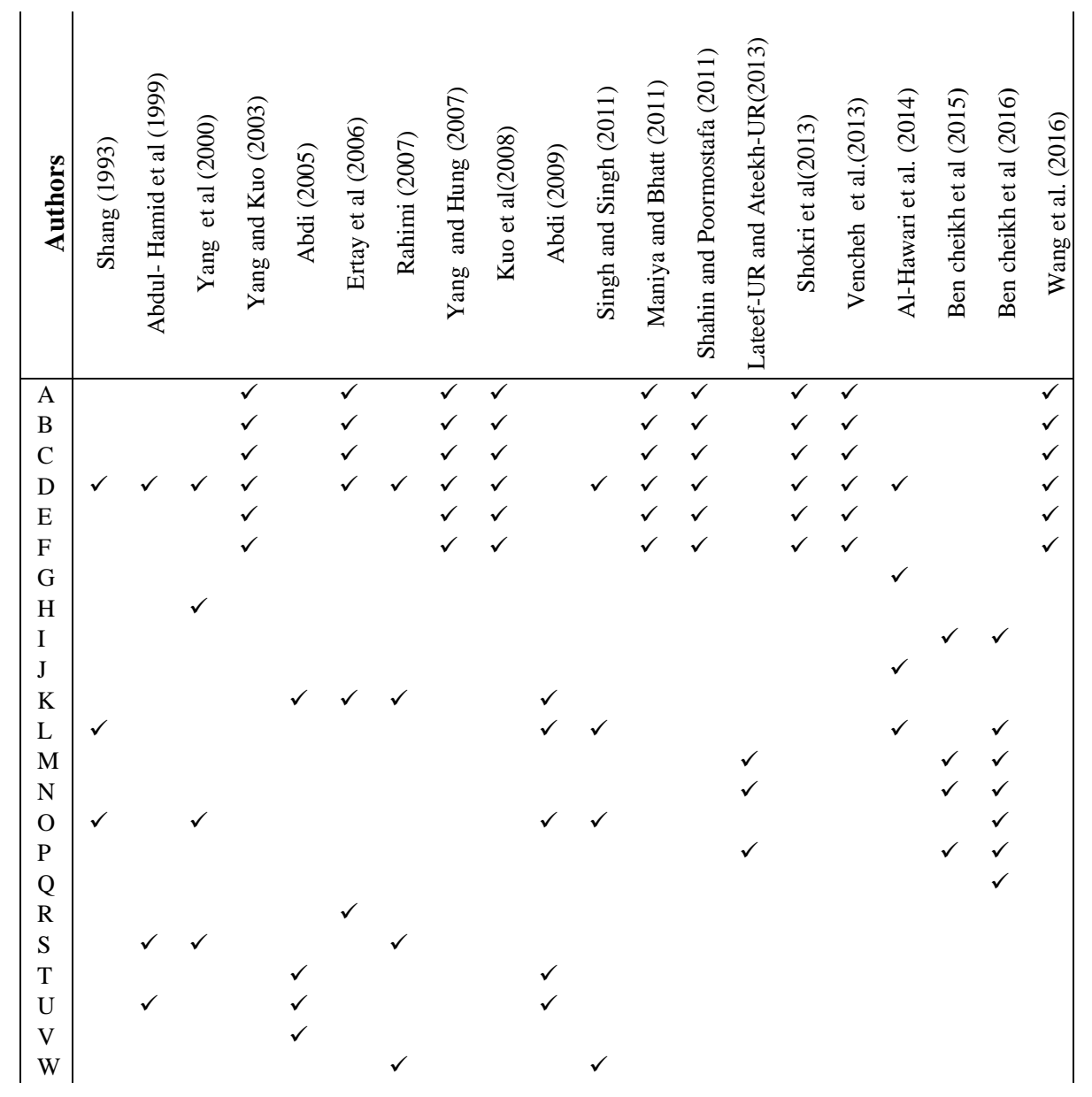

Legend

\begin{tabular}{|c|c|c|c|c|c|}
\hline A & Distance & I & $\begin{array}{l}\text { Reconfiguration } \\
\text { time }\end{array}$ & Q & $\begin{array}{l}\text { Number of machines and number of } \\
\text { operators }\end{array}$ \\
\hline B & Adjacency score & $\mathrm{J}$ & $\begin{array}{l}\text { Productive area uti- } \\
\text { lization }\end{array}$ & $\mathrm{R}$ & $\begin{array}{l}\text { Material handling vehicle utilization } \\
\text { and handling cost }\end{array}$ \\
\hline $\mathrm{C}$ & Shape ratio & $\mathrm{K}$ & Quality & $\mathrm{S}$ & Productivity \\
\hline $\mathrm{D}$ & Flexibility & $\mathrm{L}$ & Human issues clus- & $\mathrm{T}$ & Layout reconfigurability \\
\hline $\mathrm{E}$ & Accessibility & $\mathrm{M}$ & Throughput time & $\mathrm{U}$ & Cost \\
\hline $\mathrm{F}$ & Maintenance & $\mathrm{N}$ & Products indicators & $\mathrm{V}$ & Reliability \\
\hline G & Closeness gap value cluster & $\mathrm{O}$ & Work in Process & W & Flow \\
\hline $\mathrm{H}$ & Process capacity & $\mathrm{P}$ & Machine utilization & & \\
\hline
\end{tabular}




\section{Multi-criteria analysis techniques}

While the multi-objective optimization techniques search for new solutions in solution space, multi-criteria analysis techniques consider limited number of predetermined alternatives and discrete preference ratings (Tzeng and Huang 2011). In this section, we present the most frequently used techniques such Analytic Hierarchy Process (AHP), Analytic Network Process (ANP) and Technique for Order of Preference by Similarity to Ideal Solution (TOPSIS) and others.

\subsection{Analytic Hierarchy Process}

The Analytical Hierarchy Process (AHP) is a multi-criteria decision making tool developed by (Saaty 1980). It can be used for both qualitative and quantitative MCDM problems. The decision problem is structured hierarchically with different levels. AHP method uses a simple paired comparison of criteria, to measure the weights of the components of the hierarchical structure, and finally to rank the alternatives in the decision. In the case of facility layout problem, (Abdi 2005) applied AHP to evaluate and select the most appropriate layout. The alternative layouts are defined based on serial, parallel, and hybrid configurations of three machines. The AHP hierarchy consists of four evaluating criteria and eleven subcriteria of which the relative importance ratings were calculated based on decision makers requirements. (Ben cheikh et al.2016) developed an AHP-based decision making approach to select one configuration among a set of available alternatives. Configurations were evaluated based on operational and strategic indicators. AHP is used in (Abdul-Hamid et al.1999) for the layout selection problem with respect to three criteria and ten sub-criteria in order to evaluate transfer line, group technology and functional layout against these criteria. In order to overcome the inherent uncertainty in the judgements of experts at the pair-wise comparison of selection attributes, (Abdi 2009) uses fuzzy AHP to solve facility layout problem.

Some research applied integrated AHP approaches to evaluate the performance of layout and select the most suitable one. Among these articles, we find (Yang and Kuo 2003) and (Ertay et al.2006) which integrate AHP and Data Envelopment Analysis (DEA). DEA is used to evaluate Decision Making Units (DMU) (Cooper et al.2011). Each DMU convert $m$ inputs to produce $n$ outputs. The approach proposed by (Vencheh et al.2013) combines AHP and Non Linear Programming (NLP) to deal with the layout selection and evaluation problem. In (Shokri et al.2013), an integrated AHP-VIKOR methodology is developed to solve facility layout design problem. A computer-aided layout-planning tool is used to generate a number of alternatives layouts as well as their quantitative data. 


\subsection{Analytical Network Process}

Analytical network process (ANP), which was developed by (Saaty 1996), is a more general form of the AHP used in multi-criteria decision analysis. AHP structures a decision problem into a hierarchy with objective, criteria, sub-criteria and alternatives, while the ANP structures it as a network. ANP is used for the first time in (Al-Hawari et al.2014) to select the best layout based on dependent and independent criteria.

\subsection{Technique for Order of Preference by Similarity to Ideal Solution}

Technique for Order of Preference by Similarity to Ideal Solution (TOPSIS), which was developed by (Hwang and Yoon 1981), is a powerful technique in dealing with multi-criteria decision making problems. It is based on choosing the best alternative having the shortest distance from the positive-ideal solution and the farthest distance from the negative-ideal solution. (Yang et al.2007) applied TOPSIS and fuzzy TOPSIS to solve facility layout problem. The proposed methodology is applied to an IC packaging company. (Wang.P et al.2016) developed an integrated Simple Additive Weighing (SAW), TOPSIS and Grey Relational Analysis (GRA) for solving optimal facility layout design selection problem.

\subsection{Other techniques}

Many other approaches were presented to solve facility layout problem such as PROMETHEE (Lateef-UR and Ateekh-UR 2013), ELECTRE (Ateekh-Ur and Babu 2009), Grey Relational Analysis (GRA) (Yang and Hung 2007), and Preference Selection Index (PSI) (Maniya and Bhatt 2011). (Maniya and Bhatt 2011) use PSI for the selection of optimal facility layout design alternative among given alternative. The main advantage of the PSI method is that there is no relative importance between facility layout design selection attributes. (Yang and Hung 2007) evaluate the layout with respect to three quantitative and three qualitative criteria by developing Grey Relational Analysis.

\section{Discussion and conclusion}

In this paper, we presented a literature review about evaluating criteria and multicriteria decision making techniques for facility layout problem. First of all, it was found that distance is the most widely adopted criterion to examine the effectiveness of layouts followed by adjacency. There are other several criteria for evaluating configurations such as space, work flow and material handling cost. We cannot find a general model for all companies. Indeed, the criteria and configuration 
alternatives can distinct from a firm to another because of differences in product types, process flow, available technologies, economical conditions and decisionmakers requirements. Besides, the feasible layouts may differ from a planning period to another.

To overcome the difficulties in selection of alternatives among a set of predetermined alternatives, researchers use a multi-criteria decision making such as AHP, TOPSIS. These approaches share common characteristics of conflict among objectives, criteria and sub-criteria and incomparable units. Based on literature review, it was observed that AHP is the most prevalent approach for selection of the best layout due to its mathematical simplicity and flexibility. However, the main drawback is the subjectivity of judgments of experts. As a final remark, this survey can be used as a background for designers for the evaluation of layout.

Futures research may be interested in the problem of generating configurations. In fact, the commercial software available to reinforce the facility layout problems are currently restricted.

\section{References}

Abdi M R (2005) Selection of layout configuration for reconfigurable manufacturing system using the AHP. ISAHP, Honolulu

Abdi MR (2009) Layout configuration selection for reconfigurable manufacturing systems using the fuzzy AHP. Int J Manuf Technol Manag 17(1/2):149-165.doi: http://dx.doi.org/10.1504/IJMTM.2009.023783

Abdul-Hamid Y. T, Kochhar A. K, Khan M. K (1999) An analytic hierarchy process approach to the choice of manufacturing plant layout. Proceedings of Institute of Mechanical Engineers, Part B, 213:397-406.

Aiello G, Enea M, Galante G (2006) A multi-objective approach to facility layout problem by genetic search algorithm and Electre method. Robotics and Computer-Integrated Manufacturing 2006; 22: 447-55.doi: http://dx.doi.org/10.1016/j.rcim.2005.11.002

Aiello G, Scalia G.L, Enea M (2012) A multi objective genetic algorithm for the facility layout problem based upon slicing structure encoding. Expert Systems with Applications, 39:10352-10358.doi: http://dx.doi.org/10.1016/j.eswa.2012.01.125

Al-Hawari T, Mumani A, Momani A (2014) Application of the Analytic Network Process to facility layout selection, Journal of manufacturing systems, Vol.33 No. 4: 488497.doi: http://dx.doi.org/10.1016/j.jmsy.2014.04.006

Ateekh-Ur and Babu (2009) Evaluation of reconfigured manufacturing systems: an AHP framework. Int. J. Product. Qual.Manag., vol. 4, no. 2:228-246.doi: 10.1504/IJPQM.2009.023189

Ben Cheikh S, Hajri-Gabouj S, Darmoul S (2015) Reconfiguring manufacturing systems using an analytic hierarchy process with strategic and operational indicators. Industrial Engineering and Operations Management (IEOM).doi :10.1109/IEOM.2015.7093890

Ben Cheikh S, Hajri-Gabouj S, Darmoul S (2016). Manufacturing configuration selection under arduous working conditions: A multi-criteria decision approach. Proceedings of the 2016 International Conference on Industrial Engineering and Operations Management Kuala Lumpur, Malaysia, March 8-10. 
Cooper WW, Seiford LM, Zhu J, Cooper WW, Seiford LM (2011) Data envelopment analysis: history, models, and interpretations. In: Handbook on data envelopment analysis. Springer US: $1-39$.

Drira, A, Pierreval H, and Hajri-Gabouj S (2007) Facility layout problems: A survey. Annual Reviews in Control, vol. 31(2): 255-267.doi: http://dx.doi.org/10.1016/j.arcontrol.2007.04.001

Ertay T, Ruan D, Tuzkaya U R (2006) Integrating data envelopment analysis and analytic hierarchy for the facility layout design in manufacturing systems. Information Sciences, 176(3):237-262.doi:http://dx.doi.org/10.1016/j.ins.2004.12.001

Hadi-Vencheh A, Mohamadghasemi A (2013) An integrated AHP-NLP methodology for facility layout design. Journal of Manufacturing Systems, 696 32(1): 40-45.

Hwang C.L, Yoon K (1981) Multiple attribute decision making :Methods and applications ,Springer, NewYork.

Kuo Y., Yang T, Huang G.W (2008) The use of grey relational analysis in solving multiple attribute decision-making problems, Computers \& Industrial Engineering 55(1): 80 93.doi: http://dx.doi.org/10.1016/j.cie.2007.12.002

Kusiak A and Heragu, S.S (1987) The facility layout problem', European Journal of Operational Research, Vol. 29, No. 3:229-251.doi: http://dx.doi.org/10.1016/03772217(87)90238-4

Lateef-Ur R, Ateekh-Ur R (2013) Manufacturing configuration selection using multicriteria decision tool. Int J Adv Manuf Tech 65(5-8):625-639.doi: 10.1007/s00170-012-4201-5

Lin L.C, Sharp G.P (1999) Quantitative, and qualitative indices for the plant layout evaluation problem, European Journal of Operational Research 116:118-138.doi: http://dx.doi.org/10.1016/S0377-2217(98)00046-0

Maniya K. D, Bhatt M. G (2011) An alternative multiple attribute decision making methodology for solving optimal facility layout design selection problems. Computers \& Industrial Engineering, 61, 542-549.doi:http://dx.doi.org/10.1016/j.cie.2011.04.009

Meller R. D, Gau, K (1996).The facility layout problem: Recent and emerging trends and perspectives. Journal of Manufacturing Systems, 15(5):351-366.doi: http://dx.doi.org/10.1016/0278-6125(96)84198-7

Nordin N N, Lee Lai-Soon (2016) Heuristics and Metaheuristics Approaches for Facility Layout Problems: A Survey. Pertanika Journal of Scholarly Research Reviews. PJSRR 2(3): 62-76.

Rahimi N (2007) Outil d'aide à la décision pour l'aménagement des ressources de production d'une entreprise d'assemblage de cartes électroniques (pcba, "grande variété, faible volume"), Dissertation, université du Québec à Montréal.

Raman D, Nagalingam S. V, Lin, G. C. I (2009) Towards measuring the effectiveness of a facilities layout. Robotics and Computer-Integrated Manufacturing, 25/191-203.doi: 10.1016/j.rcim.2007.06.003

Saaty TL (1980) The analytic hierarchy process. New York: McGraw-Hill.

Saaty TL. Decision making with dependence and feedback: the analytic net-work process. Pittsburgh, PA: RWS Publications; 1996.

Shahin A, Poormostafa M (2011) Facility layout simulation and optimization. An integration of advanced quality and decision making tools and techniques. Modern Applied Science, 5(4), 95.doi: http://dx.doi.org/10.5539/mas.v5n4p95

Shang JS (1993) Multi-criteria facility layout problem: An integrated approach. European Journal of Operational Research 66(3):291-304.doi: 10.1016/0377-2217(93)90218-C

Shokri H, Ashjari B, Saberi M, Yoon JH (2013) An integrated AHP. VIKOR methodology for facility layout design. Ind Eng Manag Sys 12(4):389-405.doi: 10.7232/iems.2013.12.4.389 
Singh S. P, Sharma R. R. K., (2006) A review of different approaches to the facility layout problems. Int J Adv Manuf Technol, vol .30 :425-433.doi: 10.1007/s00170-005-0087-9

Singh, S.P and Singh, V.K (2011) Three-level AHP-based heuristic approach for a multiobjective facility layout problem. International Journal of Production Research, Vol. 49, No. 4:1105-1125.doi: http://dx.doi.org/10.1080/00207540903536148

Suo X (2012). Facility Layout, Manufacturing System [en línea], Faieza Abdul Aziz (Ed.), ISBN: 978-953-51-0530-5.

Tzeng G-H, Huang JJ. Multiple attribute decision making: methods and applications. Boca Raton, FL: CRC Press; 2011.

Wang P, Zhu Z, Wang Y (2016) A novel hybrid MCDM model combining the SAW, TOPSIS and GRA methods based on experimental design. Information Sciences, 345(1): 27-45.doi:http://dx.doi.org/10.1016/j.ins.2016.01.076

Yang T, Su C.T, Hsu Y.R (2000) Systematic layout planning: A study on semiconductor wafer fabrication facilities. International Journal of Operations and Production Management 20 (11):1360-1372.doi: http://dx.doi.org/10.1108/01443570010348299

Yang T, Kuo C.A (2003) A hierarchical AHP/DEA methodology for the facilities layout design problem. European Journal of Operational Research, 147(1):128-136.doi: http://dx.doi.org/10.1016/S0377-2217(02)00251-5

Yang T, Hung CC (2007) Multiple-attribute decision making methods for plant layout design problem. Robotics and Computer Integrated Manufacturing, vol. 23 :126-137.doi: http://dx.doi.org/10.1016/j.rcim.2005.12.002 